\title{
PROYEKSI METODE PENDIDIKAN MADRASAH IBTIDAIYAH MELALUI SEKOLAH DASAR TOMOE
}

\author{
Aniq Alifi
}

SMPN 2 Karanganyar Demak, Jawa Tengah, Indonesia

\begin{abstract}
Nafiul Lubab
Alumni Pascasarjana UIN Walisongo, Jawa Tengah, Indonesia o in
\end{abstract}

\begin{abstract}
PROJECTION OF EDUCATION METHOD OF ISLAMIC ELEMENTARY SCHOOL THROUGH TOMOE ELEMENTARY SCHOOL: This study aimed to describe the education method applied in Tomoe elementary school in the Tetsuko Kuroyanagi's book entitled Totto-chan: The little girl in the side of the Window. The results of this study are used as a construct of development for madrasah education methods. The nature of the research used analyst-descriptive and the type of research is the study ofliterature. The data analysis Method was using descriptive analytical method, where data is collected, classified according to the issues discussed and analyzed the content (content analysis). The results of this study revealed that there are six educational methods applied in Tomoe Elementary school as an alternative method of Madrasah Ibtidaiyah education, namely: stories method, the preferred method, the field method, the rhythm method, sociodrama - play role method, and demonstration method. The researcher finds some projections as the development of methods of education in Madrasah Ibtidaiyah oriented: (a) The education methods used is student-centered, (b) the education method is based on the society axiology, (c) liberation democratic, humanist and konsientiasi educational methods.
\end{abstract}

Key words: education method, islamic elementary school, Tomoe Elementary School

\section{A. Pendahuluan}

Sekolah telah bergeser dari tugas utamanya, awal mula sekolah pengganti orang tua yang tidak mampu lagi mengajar anaknya. Sekarang masyarakat telah menempatkan sekolah berfungsi sebagai peran pendidikan 


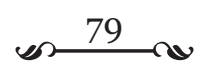

utama. Sehingga tidak heran orang tua berlomba-lomba menyekolahkan anaknya tidak asal bersekolah. Sekolah yang berlabel sekolah unggulan, sekolah model, sekolah favorit, dan lainnya. Beberapa kalangan orang tua kurang puas dengan kualitas pendidikan di sekolah pada umumnya. Hal itu, menyangkut performance guru, kelengkapan fasilitas, variasi program pengajaran dan yang lebih penting lagi adalah kualitas out-comes(apakah memiliki daya saing). Kurang puasnya orang tua seperti itu perlu refleksi, belum tentu anggapan orang tua pada sekolah tersebut sesuai dengan kriteria yang diidamkan oleh anak didik.

Persoalannya adalah bagaimana orang tua berniat demikian kadang dalam rangka demi keinginan harapan agar anaknya dapat sekolah favorit, untuk obrolan dengan teman-temannya atau demi menjaga gengsi, dan yang sering terkesampingkan adalah demi sisi pendidikan anak menghadapi masa depan menuju kepribadiannya.Permasalahan berlanjut, ketika pendidik menyampaikan materi pendidikan sekolah yang memuat pembentukan kepribadian dan penanaman nilai serta transfer of knowledgemelalui metode pendidikan sebagaimana dahulu pendidik dididik oleh pendidiknya (Chan, 2002: xxiv). Ironis sekali jika demikian keadaannya, metode pendidikan seakan-akan haram tersentuh oleh nuansa inovasi metode pendidikan yang dapat mengantarkan anak didik menghadapi persoalan hidup yang lebih komplek dari pada pendidiknya. Metode pendidikan yang pendidik terapkan telah menghilangkan kreatifitas kemanusiaan, penindasan, ketidakadilan, dominasi dan kolonisasi terhadap anak didik. Kebebasaan dan hak mengemukakan suatu pendapat atau pemikiran di-cutsedemikian rupa. Anak didik diarahkan dan dibimbing, tanpa terlebih dahulu berangkat dari mengeluarkan isi dalam pikiran anak didik sendiri. Dengan kata lain, hal ini sesungguhnya yang dinamakan penipuan pendidikan.

Orang tua harus memperhatikan sisi pendidikan anak sekolah yang sering terkesampingkan, dengan menengok diskursus kritis pendidikan sekolah yang digulirkan oleh Paulo Freire-Education of Freedom, Ivan Illich-Deschoolig Society, Margareth Mead-nenekku ingin aku mendapat pendidikan, oleh karena itu ia melarangku sekolah, Roem Topatimasangsekolah itu candu, dan Everet Reimer-School is Dead serta ahli pendidikan sealiran cukup sebagai bahan refleksi. Sebenarnya kritik itu, bukanlah keterpaksaan yang diinginkan sekolah. Justru menggugah sekolah dari kematiannya, ia akan dikaji terus menerus sebagai bagian dari proses 


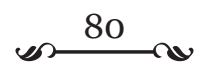

kehidupan masyarakat yang membutuhkan pendidikan sekolah (Budiman, 2001: viii). Sekolah mempunyai harapansebagai suatu lembaga mendidik anak didik menentukan kehidupan menuju kepribadiannya.

Pendidikan sekolah semestinya memahami anak didik sebagai manusia berpotensi, mempunyai dunianya sendiri, memperlakukan sebagai individu yang unik, terjalin hubungan kekerabatan antara pendidik dengan anak didik tanpa jarak menegangkan, memanfaatkan langsung pengalaman anak serta terus-menerus menggali, mengembangkan, dan menghargai pendapat anak. Intinya pendidik mengajak untuk aktif dan belajar dalam suasana yang menyenangkan (Taruna, 2002: 70). Pandangan pendidikan sekolah demikianlah yang tidak menghambat perkembangan anak didik sebagai subyek-aktor pendidikan.

Senada dengan peristiwa di atas, sekolah dasar Tomoe di Jepang dapat dijadikan bahan kajian dalam ulasan ini. Sekolah tersebut dibukukan dalam tulisan Tetsuko Kuroyanagi berjudul Totto-chan Si Gadis Kecil di Tepi Jendela. Dalam buku ini dikisahkan bermula dari ibunya Totto-chan yang tidak percaya dengan kenakalan Totto-chan di kelas. Menurut anggapan ibu gurunya, Ia sering mengganggu kelas seperti suka membuka menutup meja, memanggil pengamen atau berbicara dengan burung dari balik jendela kelas, ketika jam pelajaran sedang berlangsung. Sebab itulah mengapa Totto-chan dikeluarkan dari sekolah pertamanya, padahal baru seminggu ia bersekolah di situ.

Untungnya dari sekolah pertama ini, ibu Totto-chan mencarikan sekolah lain yang sekiranya cocok untuknya. Akhirnya, sekolah dasar Tomoe lah menjadi alternatif sekolah untuk Totto-chan, Totto-chan masuk sekolah ini tanpa seleksi pendaftaran ketat, dengan bercerita sepuas hati termasuk pengalamannya di sekolah pertama kepada kepala sekolah, ia diterima sebagai murid baru. Sekolahnya terbuat dari bekas gerbong kereta api listrik. Di sekolah ini murid-muridnya setiap hari boleh duduk di mana saja yang disukainya sesuai dengan perasaan atau urusan anak tersebut pada hari itu.

Penyampaian pelajaran kadang dengan cara seorang guru menulis semua soal untuk seluruh pelajaran yang dijadwalkan untuk hari itu di papan tulis sampai penuh. Jadi setiap murid boleh memulai dari pelajaran yang disukainya. Dengan cara ini merupakan cara yang paling tepat untuk mengetahui pribadi setiap murid.

Ada acara makan siang bersama, bekal makanan dari rumah yang 


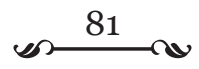

syarat makanannya adalah satu macam "yang dari gunung" dan satu macam lagi "yang dari laut," dan murid-murid menikmati bertukar makanan sambil belajar apa yang dari gunung dan apa yang dari laut. Sebelum acara makan siang dimulai masing-masing murid dituntut ketrampilan untuk bercerita terserah semau murid, apa saja boleh.

Kalau di sekolah lain ada seragam, namun di sekolah dasar Tomoe ini murid-murid dianjurkan memakai pakaian terjelek yang mereka punya. Lalu, seorang petani adalah guru, karena dialah yang paling tahu tentang tanaman dan cara berkebun. Acara jalan-jalan adalah hal yang selalu dilakukan apabila murid-murid bisa menyelesaikan seluruh pelajaran sebelum waktunya.

Pelajaran ritmik pun dipelajari, pelajaran ritmik muncul dari awal kegelisahan kepala sekolah bagaimana caranya orang-orang dewasa yang di sekelilingnya dapat mengembangkan anak-anak dengan bakat yang dibawanya sejak lahir tanpa merusaknya. Bernyanyi bersama, berenang, berkemah, menguji keberanian dan bertamasya ke laut atau pemandian air panas adalah bagian dari sekian acara sekolah yang menyenangkan anak didik untuk belajar menuju pembentukan kepribadiannya.

Sebuah pertanyaan tersirat, bila ibunya dulu tidak memindahkan ke Sekolah Dasar Tomoe, akan jadi apa Totto-chan dewasa?. Singkatnya, Tottochan kemudian tumbuh dewasa berbekal kenangannya selama dua tahun di sekolah dasar Tomoe. Hingga akhirnya sekolah ini kemudian hancur oleh serangan pesawat pembom B-29 Amerika (Nagaki, 1993: vii).Tapi Totto-chan tidak pernah lepas membanggakannya. Apalagi dari Sekolah Dasar Tomoe muncul muridnya yang ahli fisika terkemuka, ahli anggrek tersohor dan tentu Totto-chan sendiri (Mohammad, 1989: 376-377).

Seandainya saat ini Sekolah Dasar Tomoe masih ada, mungkin tidak seorang anak pun yang segan pergi ke sekolah. Semua anak tidak sabar untuk kembali ke sekolah untuk esok harinya. Benar-benar sekolah sebuah impian. Dengan demikian bagaimana membuat anak didik senang bersekolah dengan tidak mengesampingkan sisi pendidikan anak menuju kepribadiannya. Berawal dari sini, penulis tertarik untuk mengkaji lebih jauh metode pendidikan yang diterapkan Sekolah Dasar Tomoe dalam buku Totto-chanSi Gadis Kecil di Tepi Jendela tulisan Tetsuko Kuroyanagi sebagai konstruksi metode pendidikan Islam khususnya pada metode pendidikan di Madrasah Ibtidaiyah. 


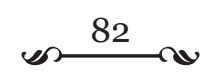

\section{B. Pembahasan}

\section{Pengertian Metode Pendidikan SD Tomoe}

Metode berasal dari bahasa Yunani "metodos", yakni dari dua suku kata, yaitu "metha" yang berarti melalui atau melewati dan "hodos" yang berarti jalan atau cara. Metode berarti suatu jalan yang dilalui untuk mencapai tujuan (Arifin, 1996: 61). Metode diartikan juga sebagai "cara" bukan "langkah" atau "prosedur.” Metodeyang diartikan cara mengandung pengertian fleksibel sesuai kondisi dan situasi serta mengandung implikasi mengaruhi saling ketergantungan antara pendidik dengan peserta didik. Sedangkan metode dalam arti "langkah" atau "prosedur" lebih bersifat teknis administratif atau taksonomis seolah-olah mendidik atau mengajar hanya diartikan sebagai langkah aksiomatis, kaku, dan tematis. Dalam pengertian "cara" ini, antara pendidik dan anak didik berada dalam proses kebersamaan menuju ke arah tujuan tertentu (Arifin, 1995: 100-101).

Seringkali kata pendidikan digantikan dengan kata pengajaran, pendidikan dan pengajaran merupakan dua istilah yang terdapat persamaan dan perbedaan. Pengajaran adalah suatu kegiatan yang menyangkut pembinaan anak mengenai segi kognitif dan psikomotorik semata. Sedangkan pendidikan mencakup kognitif, psikomotorik, dan afektif. Kemudian tujuan pengajaran lebih mudah ditentukan daripada tujuan pendidikan. Tujuan pendidikan menyangkut seluruh kepribadian manusia yang sulit ditentukan. Sebenarnya tujuan pengajaran juga menyangkut kepribadian manusia. Dengan demikian pengajaran merupakan bagian dari pendidikan (Tafsir, 1994: 27 dan Purwanto, 2002: 150-151). Sebenarnya bukan suatu yang prinsip memperbincangkan perbedaan dan persamaan antara pendidikan dan pengajaran, yang penting setiap orang yang berusaha "mendidik" anak dilakukan dengan "mengajar"-kan suatu perbuatan, ketrampilan, dan pengetahuan kepada anak didiknya. Di samping itu memahami tidak semua perbuatan "mengajar" adalah "mendidik."

Selanjutnya metode pendidikan adalah cara yang tepat guna untuk menjelaskan materi pendidikan kepada anak didik dalam situasi dan kondisi tertentu. Materi pendidikan tersebut diharapkan memberi kesan yang mendalam pada diri anak didik (Jalaluddin, 1996: 53), pengertian ini mengarah pada model pendidikan paedagogik, yakni mendidik anak. Dalam istilah tertentu metode pendidikan ini dapat disejajarkan 


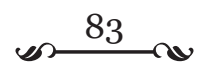

dengan strategi belajar mengajar atau kegiatan belajar mengajar. Karena mengingat proses pendidikan atau belajar ini terjadi antara pendidik sebagai orang dewasa yang bertanggungjawab menjelaskan materi pendidikan kepada anak didiknya dan anak didik sendiri sebagai subyek maupun obyek pendidikan.

Pembahasan berikutnya tentangSekolah Dasar Tomoe adalah salah satu Sekolah Dasar di Jepang tepatnya di dekat stasiun Jiyogaoka Lin Toyoko yang didirikan oleh Bapak Sosaku Kobayasi pada tahun 1937 M dan terbakar habis dibom pesawat B-29 Amerika pada perang Dunia II tahun 1945(Kuroyanagi, 1986:177). SD Tomoe ini berasal dari buku yang berjudul Totto-chan Si Gadis Kecil di Tepi Jendela yang dicetak oleh PT. Pantja Simpati, Jakarta tahun 1985 merupakan terjemahan dari buku Madogiwa No Totto-chan, kerjasama yayasan Karti Sarana dengan bantuan penerbit Toyota Foundation Jepang. Buku tersebut adalah kisah nyata anak Totto-chan sebagai respon pendidikan Jepang terhadap anak yang dianggap nakal, namun sebenarnya adalah anak cerdas dan baik. Begitu juga Kompas Minggu menyatakan: “Anak-anak pun tampaknya tidak punya alasan menolak kehadiran Totto-chan. Kisah masa kecil Tetsuko Kuroyanagi sungguh-sungguh memikat. Para orang tua lewat kisah ini juga akan terpengaruh. Kalau Ivan Illich menawarkan "bebas dari sekolah," maka penulis menyodorkan "sekolah yang bebas."dengan judul bahasa Inggris Totto-chan: The Little Girl at The Window diterbitkan oleh Kodansha Internasional terjual lebih dari tujuh juta copy dan buku terjemahannya diterbitkan di tiga puluh tiga Negara. Buku ini pernah ditunjuk sebagai perwakilan UNICEF pada tahun 1984. Tetsuko Kuroyanagi juga dianugrahi penulis cerita humor dan kontribusinya dalam literatur beberapa majalah (http://www.learningfamily.com).

Pada pembahasan berikutnya adalah MI (Madrasah Ibtidaiyah) ini sederajat dengan SD pada pendidikan dasar (UU No. 20 Tahun 2013 tentang Sistem Pendidikan Nasional pasal 17 ayat 1 dan 2), kemudian dalam pemaknaan peraturan yang lainnya sebagaimana dalam PP No. 17 Tahun 2010 tentang Pengelolaan dan Penyelenggaraan Pendidikan pasal 1 ayat 9 menjelaskan Madrasah Ibtidaiyah ialahsalah satu bentuk satuan pendidikan formaldalam binaan Menteri Agama yangmenyelenggarakan pendidikan umum dengankekhasan agama Islam pada jenjang pendidikandasar.Berdasarkan beberapa definisi tersebut di atas, penulis akan menganalisis buku tersebut, dengan mengungkapkan 


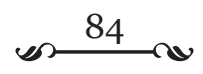

bagaimana metode pendidikan yang diterapkan pendidik terhadap anak didik dalam proses pendidikan Sekolah Dasar Tomoe untuk kemudian sebagai konstruk dalam mengembangkan metode pendidikanyang ada di Madrasah Ibtidaiyah.

\section{Paradigma Substansi Metode Pendidikan SD Tomoe}

Peserta didik sangat dipertimbangkan dalam proses pendidikan, apalagi dalam masa paling lemah dalam perjalanan hidup manusia adalah masa anak-anak. Kondisi ruhaniah dan badaniahnya belum lengkap berkembang, ketrampilan untuk menunjang hidup amat minim serta kecenderungan mereka amat berbeda dengan orang dewasa, menyebabkan mereka memiliki dunia tersendiri, dunia anak-anak. Tetap saja kehidupan mereka bergantung sepenuhnya kepada kebaikan orang dewasa di sekitarnya. Tanpa orang dewasa, tidak mungkin manusia kecil mampu bertahan hidup sendirian (Sa'abah, 2001: 90).

Sementara pada sisi psikologi, anak perlu diperhatikan oleh orang dewasa dalam hal ini adalah pendidik, yang nantinya akan menuntut beberapa hukum dasar yang juga perlu diperhatikan pendidik dalam proses pendidikan: (1) perbedaan sifat kepribadian unik yang dimiliki oleh setiap anak yang terbentuk oleh faktor keturunan (hereditas), lingkungan (environment), dan diri (self). (2) Kecerdasan yang dimiliki anakoleh masing-masing anak. (3) ciri-ciri tertentu pada setiap tahap pertumbuhan (Tim Dosen IKIP Malang, 1980: 107-116).

Ciri-ciri masa kelas rendah SD (kelas I-III) antara lain: adanya korelasi yang tinggi antara kesehatan pertumbuhan jasmani dengan prestasi sekolah, cenderung untuk mematuhi peraturan permainan tradisional, cenderung memuji diri sendiri, jika tidak dapat menyelesaikan soal, maka dianggap soal tersebut tidak penting, yang utama siswa pada kelompok ini menginginkan nilai raport yang baik (Syadli, 2001: 171).

Di sinilah pentingnya untuk mengetahui keadaan anak menuju manusia dewasa. Dalam pandangan Wens Tanlain ciri manusia dewasa ini memiliki karakteristik sebagai berikut: (1) mempunyai individualitas yang utuh, (2) mempunyai sosialitas yang utuh, (3) mempunyai norma kesusilaan dan norma kesusilaan, dan (4) bertindak sesuai norma dan nilai-nilai itu atas tanggung jawab sendiri demi kebahagiaan dirinya, masyarakat dan orang lain (Tanlain, 1996: 29). Hal ini merupakan 


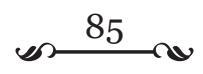

perhatian besar orang tua terhadap anak sampai-sampai dimasukkan ke sekolah. Sekolah sebagai lembaga pendidikan yang mendidik anak, biasanya umur 6-7 tahun. Jadi usia anak sekolah dasar atau madrasah ibtidaiyah dibedakan menjadi dua yaitu: masa kelas rendah sekitar usia 6-9 tahun dan masa kelas tinggi sekitar usia 10-13 tahun (Munandar, 1985: 1). Anak-anak tersebut mulai sekolah dasar yang akhirnya disebut siswa.

Ibu Totto-chan salah satu orang tua yang memperhatikan pendidikan anaknya. Setelah peristiwa dikeluarkan dari sekolah pertamanya, ibu Totto-chan ini memilih SD Tomoe sebagai pendidikan untuk anaknya. Awalnya ibu Totto-chan khawatir dengan keadaan SD Tomoe, namun lama-kelamaan rasa itu mereda, ketika memahami pendidikan sekolah yang diterapkan dapat membuat kerasan dan belajar dengan senang anak didiknya. Anak-anak senang pergi ke sekolah dan tak ingin cepat pulang serta menanti kembali jelang esok pagi untuk pergi ke sekolah lagi (Kuroyanagi,1986 :23).

Bapak Kobayashi merintis SD alternative, otonom tanpa ada intervensi pemerintah atau ideologi tertentu (Kuroyanagi, 1986:8). Sekolah ini didirikan untuk memenuhi hak anak untuk memperoleh pendidikan. Bapak Kobayashi menegaskan kebijakannya dalam pendidikan, seperti kebebasan pendidikan dan menjunjung tinggi pribadi anak-anak. Misalnya pelajaran diakhiri pada pagi hari dan sorenya diisi dengan acara jalan-jalan, mengumpulkan tanaman, mendengarkan cerita guru, menyanyi dan sebagainya. Hal demikian diterapkan dengan metode pengajaran bapak Kobayashi di SD Tomoe.

Selanjutnya metode pendidikan yang diterapkan SD Tomoe, berorientasi dari pembahasan sebagaimana pengertian metode pendidikan di atas, penulis merangkum dengan menamakannya sebagai berikut:

a. Metode cerita

Metode cerita adalah suatu cara mengajar yang pada hakekatnya sama dengan metode ceramah, karena informasi yang disampaikan melalui penuturan atau penjelasan lisan dari seseorang kepada orang lain. Dalam metode cerita, baik guru maupun siswa dapat berperan sebagai penutur. Guru dapat menugaskan salah seorang siswa atau lebih untuk menceritakan suatu peristiwa atau topik (Shaleh, 2000: 72). 


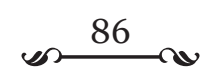

Berdasarkan pengertian tersebut metode cerita di SD Tomoe ini nampak pada kegiatan bercerita yang digunakan pertama kali, saat Tottochan masuk SD Tomoe (Kuroyanagi, 1986:19-21), dan selanjutnya dipakai dalam mengisi acara makan siang sedang berlangsung (Kuroyanagi, 1986:86-89), serta kegiatan ke kuil Sengakuji berupa cerita oleh bapak Maruyama (Kuroyanagi, 1986:106). Kegiatan ini penekanan pada murid murid untuk menceritakan pengalamannya terserah mau cerita apa, yang penting murid-murid dapat mengeluarkan sepatah dua patah kata untuk bahan pembicaraan di depan teman-temannya (Kuroyanagi, 1986:57), kecuali saat ke kuil Sengakuji bapak Maruyama yang bercerita.

Dari kebiasaan bercerita ini nantinya diharapkan tumbuh pribadi yang dapat menguasai forum dan tidak takut di muka umum (Kuroyanagi, 1986:87), dan cerita bapak Maruyama memberi penjelasan dan semangat kepada anak didiknya (Kuroyanagi, 1986:160). Dalam cerita antara pendidik dengan anak didik, terdapat perbedaan dalam penekanannya siapa yang bercerita, di sekolah Tomoe anak didik lebih dituntut keaktifannya bercerita dari pada pendidiknya.

b. Metode pilihan

Metode pilihan di SD Tomoe nampak pada cara penyampaian pelajaran, kadang melalui seorang guru menulis semua soal untuk seuruh pelajaran yang dijadwalkan untuk hari itu di papan tulis sampai penuh. Pelajaran yang di dalamnya ada persoalan bagi murid tertentu, saat itu juga dipertanyakan dan guru menjawabnya. Setiap murid boleh memulai dari pelajaran yang disukai (Kuroyanagi, 1986: 28).

Metode pilihan belum mulai dengan pelajaran yang memerlukan cara belajar sendiri, tetapi tetap berlaku juga cara mulai belajar dari pelajaran yang paling disukai. Ada anak yang menulis huruf Katakana atau Hiragana di dalam catatannya, ada yang menggambar, ada yang membaca buku dan di antaranya ada pula anak yang melakukan senam, inilah cara belajar sejati. Dengan demikian, hampir tidak ada kesenjangan bagi murid untuk mendengarkan petuah atau pelajaran guru yang diberikan secara searah tanpa berpikir. Dengan cara ini bertujuan untuk mengetahui pribadi setiap murid, karena dari pelajaran yang paling disukai muncul kecenderungan bakat dan minat anak didik (Kuroyanagi, 1986: 29). 


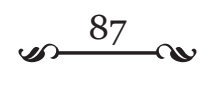

c. Metode karya wisata

Metode karya wisata adalah suatu metode pengajaran yang dilaksanakan dengan jalan mengajak anak keluar kelas untuk memperlihatkan hal-hal atau peristiwa yang ada hubungannya dengan pelajaran. Metode ini merupakan alternatif yang diperuntukkan bagi siswa agar mendapatkan pengalaman belajar yang tidak diperolehnya secara langsung di dalam kelas. Hal ini sebagai selingan out door study sebab para siswa diajak langsung kealam yang sebenarnya (Arief, 2002: 168).

Metode karya wisata ini antara lain, dengan acara jalan-jalan adalah hal yang selalu dilakukan apabila murid-murid bisa menyelesaikan seluruh pelajaran sebelum waktunya dan anggapan murid murid acara jalan jalan hanya sebagai waktu bermain main. Mereka belum menyadari sebenarnya acara ini merupakan kesempatan berharga untuk belajar ilmu pasti, alam, dan biologi secara nyata (Kuroyanagi, 1986: 36). Berkemah meskipun dalam ruangan kelas pun dilakukan anak didik dan ini membentuk petualangan (Kuroyanagi, 1986: 55-56), begitu juga bertamasya ke laut atau pemandian air panas adalah bagian dari metode karya wisata yang menyenangkan anak didik untuk belajar menuju mencintai dan mengenal lingkungannya (Kuroyanagi, 1986: 67-71).

c. Metode sosio drama dan bermain peran

Metode sosiodrama adalah suatu cara mengajar yang memberikan kesempatan kepada siswa untuk melakukan kegiatan memainkan peranan tertentu seperti yang terdapat dalam kehidupan masyarakat (kehidupan sosial). Dalam metode sosiodrama siswa dibina agar terampil menggambarkan atau mengekspresikan sesuatu yang dihayati. Metode bermain peran ialah suatu cara penguasaan bahan pelajaran melalui pengembangan imajinasi dan penghayatan siswa. Pengembangan imajinasi dan penghayatan dilakukan siswa dengan memerankan dirinya sendiri sebagai tokoh hidup atau benda mati, karena kegiatan memerankan akan membuat siswa lebih meresapi perolehannya (Shaleh, 2000: 70-71).

Menguji keberanian inilah berupa metode sosiodrama dan bermain peran di sana anak-anak sebagian berperan sebagai hantu dan lainnya sebagai anggota yang ditakuti, namun dari keduanya yang berperan hantu dan anggota sama-sama diuji keberaniannya, sejauh 


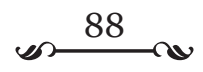

mana anak-anak dalam menguasai rasa takutnya (Kuroyanagi, 1986: 62-64). Acara ini bertempat di kuil Kuhonbutsu. Murid-murid dibagi dalam beberapa kelompok, masing-masing ada kelompok yang menjadi hantu dan kelompok lainnya menjadi anggota biasa. Tiap kelompok lima orang, setiap kelompok harus berangkat selang beberapa waktu setelah kelompok hantu berangkat dari sekolah. Kemudian kelompok-kelompok itu harus menempuh jalan mengelilingi kuil dan kuburan Kuhonbutsu sebelum kembali ke sekolah. Jika sudah merasa takut boleh langsung kembali ke sekolah. Acara ini bertujuan agar anak didik dapat menguasai rasa takutnya(Kuroyanagi, 1986: 62).

d. Metode ritmik

SD Tomoe mempunyai cara belajar yang berbeda dengan SD biasa, misalnya di SD Tomoe ada pelajaran musik, antara lain ada jam pelajaran ritmik. Ritmik ini suatu pendidikan gerak khusus yang dicetuskan oleh seorang pemusik dan composer Swiss bernama Dalcroze. Tekniknya mulai dikenal pada sekitar tahun 1904. Sistem yang dipakai di seluruh Eropa dan Amerika serta sampai di beberapa negara didirikan tempat pendidikan dan latihan atau lembaga penelitiannya (Kuroyanagi, 1986: 72).

Kalau ditanya ritmik itu apa?, bapak Kobayashi menjelaskan ritmik adalah permainan yang mengajarkan ritme irama pada hati dan tubuh, dengan melakukan ritmik sifat seseorang menjadi ritmis. Sifat yang ritmis itulah indah serta kuat dan menuruti hukum alam secara luwes. Pelajaran ritmik ini muncul dari awal kegelisahan kepala sekolah bagaimana caranya orang-orang dewasa di sekelilingnya dapat mengembangkan anakanak dengan bakat yang dibawa sejak lahir tanpa merusaknya. Karena, pendidikan zaman sekarang yang terlalu bergantung pada huruf dan bahasa mungkin telah menyebabkan kepekaan anak-anak untuk melihat alam lewat hati, menangkap bisikan, dan menerima ilham. Metode ritmik diterapkan dalam pelajaran sekolah dengan harapan dapat melahirkan perasaan yang peka terhadap lingkungan (Kuroyanagi, 1986: 73-76).

Metode demonstrasi

Termasuk dalam metode ini ialah pelajaran pertanian dari guru baru yang berkostum petani. Beliau adalah petani yang memiliki kebun bunga di dekat sekolah dan sekarang menjadi guru berladang. Pak Kobayashi tidak memperdulikan berbagai peraturan atau syarat untuk 


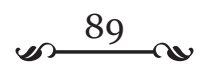

menjadi guru seperti di SD lain, karena kepala sekolah ingin anakanak belajar mengenal lingkungan dengan melihat sendiri seseorang melakukan pekerjaan.

Pak guru pertanian memulai pekerjaannya mencabut rumput sambil menjelaskan tentang tidak berguna, kekuatan, jenis, dan pertumbuhannya rumput yang lebih cepat dari tanaman lain, sehingga menghalangi sinar matahari bagi tanaman itu, yang merupakan tempat persembunyian serangga dan hama, merebut gizi dalam tanah dan lain-lain dengan gaya menarik, seolah menjadi bukti bahwa cerita itu berdasarkan pengalaman dan hasil temuannya sendiri. Ia menerangkan segalanya sambil memeragakan cara-caranya (Kuroyanagi, 1986: 124-125). Bapak guru pertanian dalam menyampaikan pelajaran ini menggunakan metode demonstrasi, yakni salah satu teknik mengajar yang dilakukan oleh seorang guru dengan sengaja meminta siswa sendiri ditunjuk memperlihatkan kepada kelas tentang suatu proses atau cara melakukan suatu pekerjaan (Usman, 2002: 45).

Begitulah ilustrasi tentang keberadaan metode pendidikan SD Tomoe dalam buku Totto-chan Si gadis kecil di tepi jendela yang terdiri dari metode cerita, metode pilihan, metode karyawisata, metode sosiodrama, metode ritmik, dan metode demonstrasi. Sekilas metode pendidikan yang diterapkan tidak jauh berbeda dengan metode pendidikan yang pada umumnya diterapkan di sekolah lainnya. Namun yang lebih spesifik, sebenarnya dalam dataran praktis-operasionalnya terdapat titik tekan yang berbeda pada masing-masing metodenya. Inilah kemudian sebagai langkah lanjut analisis wacana metode pendidikan SD Tomoe dalam mengkonstruk metode pendidikan di MI.

\section{Peta Pemikiran Pendidikan Islam dalam Metode Pendidikan MI}

Perkembangan sistem pendidikan di Indonesia pada dasarnya terdapat kelemahan utama pada penekanan lebih mementingkan materi daripada metode (Mastuhu, 1999: 59). Keadaan metode pendidikan ini menuntut pembenahan untuk merajut tangga kesuksesan ke depan. Lagi pula pendidikan memang harus kembali memposisikan diri menjadi agen perubahan dan penentu sebuah tatanan masyarakat. Senantiasa belajar dari pengalaman sendiri maupun orang lain adalah langkah preventif terhadap munculnya kegagalan yang akan datang.

Upaya menciptakan situasi demikian menuntut pendidik tentunya 


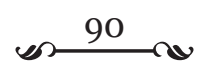

mampu mendidik dengan kompetensi terpadu, dalam artian pendidik mempunyai tanggungjawab atas pendidikan anak didik. Di sinilah artinya kerjasama antara pendidik dengan orang tua. Kondisi ini diperkuat bahwa pada umumnya orang tua cenderung kurang mengerti bagaimana cara mendidik anak, sementara di sisi lain, banyak lingkungan yang memiliki sifat kurang bersahabat, sehingga peran pendidik memiliki nilai strategis. Begitu strategisnya peran pendidik, sebagaimana Rofik (2003: 112) mengutip pendapat Mukhtar Yahya merekomendasikan selayaknya pendidik itu memiliki sifat-sifat yang jelas dan ideal yang membantunya dalam kesempurnaan ilmu dan kesuksesan fungsi. Pendidik ideal ialah yang memiliki sifat aqliyyah (intelektualitas), jasmaniyah (fisik), dan akhlaqiyyah(moralitas).

Wacana tersebut mengungkap tentang pendidik pada masa klasik yang disebut muaddib (al-Abrasyi, 1993: 141), sedangkan SD dalam pendidikan Islam menurut para peneliti dalam pendidikan Islam klasik sepakat bahwa maktab atau kuttab secara harfiah berarti tempat untuk mengajar dan menulis merupakan lembaga pendidikan dasar (school for elementary education) (Tritton, 1957: 1, Zuhairini, 1997: 89). Saat wilayah Islam berkembang pada saat itu kuttabjuga berkembang pada berbagai dunia Islam. Naskoteen (1995: 63) menyebut eksistensi kuttabini pada perkembangannya di Spanyol, Silsilia, Afrika, dan Timur Tengah. Pada pemerintahan Umayyah dan Abbasiyyah lembaga ini dicatat kontribusinya dalam memperkenalkan pengajaran membaca dan menulis dasar, tentu dengan kandungan kurikulum yang berbeda-beda sesuai dengan kebutuhan sosial budaya setempat. Pada pertengahan abad IV H, ketika diperkenalkan dana pemerintahan dan pendirian sekolah umum (madrasah) keberadaan kuttab menjadi menurun.

Pada saat itu sederhananya materi pendidikan SD atau kuttab yang berkutat pada al-Qur'an berarti metode yang diterapkan kurang begitu menyentuh pada aspek metode pendidikan yang rumit, hanya pengajaran membaca dan menulis. Kemudian berbagai metode pendidikan Islam muncul seiring perkembangan yang diukur dari seberapa modern media yang digunakan oleh setiap pendidik dalam mengaplikasikan metode yang ada. Karena pada dasarnya metode-metode tersebut tidak ada yang tertinggal pada setiap periode. Di samping diakui banyak metode yang lahir sesuai dengan perkembangan pemikiran dan kebutuhan zaman 


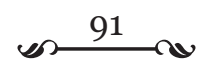

(Asari, 1999: 83).

Selanjutnya muncul metode pendidikan Islam dalam mengantarkan proses pendidikan anak didik seperti Abdurrahman an-Nahlawi membagi menjadi tujuh metode pendidikan Islam yang diterapkan di sekolah, keluarga, dan masyarakat: metode dialog qur'ani dan nabawi, kisah-kisah qur'ani dan nabawi, perumpamaan qur'ani dan nabawi, keteladanan, aplikasi dan pengalaman, ibrah, dan nasehat, dan terakhir targhib dan tarhib(an-Nahlawi, 1995: 204).

Omar Mohammad al-Toumy al-Syaibani (1979: 560-579) menyebutkan metode induktif, metode qiyasiyah, metode kuliah, metode dialog dan perbincangan, metode halaqoh, metode mendengar, metode hafalan, metode pemahaman dan metode lawatan. Sementara Muhammad Qutb (1993: 32) menyebutkan metode pendidikan Islam terdiri dari pendidikan melalui teladan, hukuman, cerita-cerita, pembiasaan dan pengalaman konkrit.Dalam literatur terdapat berbagai macam metode pendidikan Islam yang ditulis oleh pakar pendidikan Islam dan masingmasing pendapat tersebut tidak jauh berbeda dalam dataran penamaan konsepsional dan praktis-operasional, terutama pendapat Basyaruddin Usman (2002: 33-34) menjelaskan metode pendidikan Islam seperti ini dikatakan konvensional yang antara lain: metode ceramah, diskusi, tanya jawab, demonstrasi dan eksperimen, resitasi, kerja kelompok, sosiodrama, dan bermain peran, karyawisata, drill, dan sistem regu.

Perbandingan metode di atas lebih luas lagi memaparkan pendapat Zakiah Daradjat dengan tinjauan psikologi anak SD dengan praktik pendidikan M. Athiyah al-Abrasyi, maka nuansa baru lebih cerah dalam metode pendidikan Islam lebih muncul beraspek pada anak didik sebagai subyek dan obyek pendidikan.Zakiah Daradjat (1995: 80) mengatakan bahwa psikologi anak ketika umur 6-7 tahun ditandai dengan pemikiran logis terus tumbuh dan berkembang dengan cepat sampai umur 12 tahun, di mana anak-anak mampu memahami hal yang abstrak, mampu memahami pelajaran yang memerlukan pemikiran, dapat dilatih disiplin ringan atau sederhana, suka mendengarkan cerita dengan perkembangan kecerdasannya, suka fantasi dan tidak jarang mereka merasa bahwa pahlawan cerita itu adalah dirinya sendiri-mengidentifikasi dirinya sebagai tokoh cerita tersebut.

Ide ini menurut penulis melangkahkan suatu teori pendapatnya 


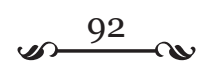

M. Athiyah al-Abrasyi bahwa tugas guru hendaknya menuntun muridmurid di saat ia membutuhkan tuntunan, sehingga ia merasakan lezatnya belajar, dan guru memberikan kemerdekaan bekerja sendiri, sehingga ia terbiasa dengan kerja bersungguh-sungguh dan secara terus-menerus, percaya pada diri sendiri, mengatasi sendiri kesukaran-kesukaran kalau ada, melatih diri untuk bekerja secara teliti dan dengan sebaik-baiknya (al-Abrasyi, 1993: 16). Namun sayangnya, konsep metode pendidikan Islam berlandaskan pada idealisme Islam yang didukung wahyu Allah SWT. Jadi wacana yang dikembangkan metode pendidikan Islam masih cenderung pada tataran teoritis, maka ia lebih menekankan pada aspek teoritis daripada sekedar praktis, meskipun keduanya saling berkaitan.

Sehubungan dengan konsep tersebut dataran teoritis pada metode pendidikan Islam yang pemahamannya terhadap teks normatif wahyu illahi (al-Qur'an dan Hadits) ikut mempengaruhi wacana tentang model pendidikan Islam yang sedang dan terus akan berkembang seiring dengan keberadaan ruang dan zaman. Hal ini yang menimbulkan akses ideologi tertentu terhadap metode pendidikan, yang dibawa oleh wahyu untuk diterapkan dalam kehidupan dinamis, yang oleh seorang intelektual dapat ditangkap sebagai sebuah sistem idealyang sejalan dengan pemikiran rasional dari hukum alam (Hanafi, 2003: 9), implementasi problemnya adalah ketika guru ini kadang dalam proses pendidikan cenderung ada penekanan mendasar terhadap anak didik untuk tidak melakukan hal yang kiranya keluar dari batas-batas pemahaman ideologi yang diidealkan menurut subyektifitas pendidik. Di sinilah urgensi wacana metode pendidikan SD Tomoe penulis kemukakan, angkat, dan kaji dalam proyek untuk mengkonstruk metode pendidikan Islam di Madrasah Ibtidaiyah.

\section{Proyeksi Metode Pendidikan Sekolah Dasar Tomoe sebagai Konstruk Metode Pendidikan Madrasah Ibtidaiyah}

Program perluasan kesempatan belajar hampir menyerap seluruh sumber daya yang ada. Tidaklah mengherankan, jika selama ini perluasan kesempatan belajar mendapat prioritas dibandingkan dengan dengan pembinaan mutu pendidikan dasar. Dalam keadaan ekonomi yang paling sulit, harapan untuk dapat meningkatkan kualitas pendidikan dasar tidak pernah absen. Usaha-usaha ke arah itu, termasuk kegiatan penelitian terus dilakukan. Selanjutnya dengan menduduk-sandingkan bahasan persoalan 


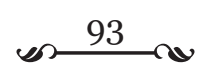

metode pendidikan Islam nampak beberapa hal yang menjadi catatan penulis bahwa metode pendidikan SD Tomoe dalam sudut pandang pendidikan Islam disadari atau tidak disadari telah membuka teori baru untuk memadukan berubah menjadi suatu konstruk baru berupa pendidikan yang masih dalam dataran nilai-nilai pendidikan Islam.

Penamaan metode pendidikan Islam yang bersumber wahyu Illahi serta berawal dari problem pemikiran empirik pakar pendidikan Islam sebagaimana pada tulisan point 3 di atas tentang pemikiran dan problematika metode pendidikan Islam dalam Madrasah Ibtidaiyah seperti dalam metode pendidikan SD Tomoe berupa: metode cerita, metode pilihan, metode karyawisata, metode sosiodrama-bermain peran dan demonstrasi dari sisi bahasa telah ada dalam penamaan-penamaan sebelumnya dalam metode pendidikan Islam di lembaga MI. Hal tersebut berlainan dengan metode pilihan dan metode ritmik.

Bahasan ini lebih rincinya mengungkap pula tentang paradigma pendidikan SD Tomoe, yang didasari pada model pendidikan yang independen. Penulis secara langsung mengutip istilah-istilah yang sesuai dengan apa adanya tekstualis dari buku Totto-chan si Gadis Kecil di Tepi Jendela dengan mempertimbangkan sudut pandang materi apa yang disampaikan pendidik terhadap anakdidik serta tujuan dari pendidikan tersebut.

Sebenarnya metode pilihan ini terkandung di dalamnya praktek proses metode tanya jawab, dialog, diskusi, namun sisi-sisi anak didik dalam menentukan kebebasannya untuk memilih pelajaran mendapat prioritas yang kemungkinan besarnya berada dalam posisi tawar yang benar-benar diperhatikan oleh pendidik. Begitu pula ilustrasi metode ritmik dalam kata sederhananya metode pendidikan yang berhubungan dengan nada atau ritmik dengan gerak tubuh.

Sandaran penamaan ritmik secara konsepsional berkenaan dengan metode pendidikan Islam pun belum dikenal metode ritmik dan ini secara langsung memberi nuansa baru dalam tekstualitas bahasa, untuk kemudian praktis-operasionalnya berubah ke kontekstualitas dalam metode pendidikan Islam, kalau pun itu ada ketersinggungan dengan metode pendidikan Islam paling tidak yang mengarah ke kegiatan "olahraga" dan seni musik berupa "rebana" dan itupun belum ada penamaan tersendiri dalam metode pendidikan Islam. 


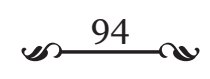

Demikian pula dalam wacana metode pendidikan secara keseluruhan selain metode pendidikan pilihan dan ritmik, seperti metode cerita, metode karyawisata, metode sosiodrama-bermain peran dan metode demonstrasi diakui secara konsepsional bahasa penulis mengatakan sama, namun sesungguhnya praktis-operasionalnya yang berbeda. Jika disandingkan dengan metode pendidikan Islam yang tertera penamaannya menurut pakar pendidikan Islam di atas. Sebagai catatan akhir penulis ialah karena model pendidikan yang dibangun SD Tomoe berupa paradigma dan ini lain dengan ideologi, maka independensi kekritisan SD Tomoe bernilai lebih progresif dalam gerak ruang dan waktu yang leluasa, dan ini segi penamaan metode pendidikan, metode pilihan, dan metode ritmik terlegitimasi secara implisit maupun eksplisit. Walaupun sementara sisi tertentu untuk kemajuan suatu hal ideologi pun sangat dibutuhkan demi kemapanan. Akan tetapi, proses kehidupan lebih dari itu, hidup ini akan terus membentang serta ketat-syarat dengan dinamika perubahan.

Dari sekian metode pendidikan yang diterapkan SD Tomoe yaitu: metode cerita, metode pilihan, metode sosiodrama dan bermain peran, ritmik, dan demonstrasi ditilik secara letterlek memang sama, namun ditilik secarateliti berbeda halnya dalam praktis-operasional. Hubungan antara guru-murid berproses tidak sama, ketika melakukan metode cerita murid lebih ditekankan pada cerita mereka tentang keadaan pengalaman yang sesungguhnya ia hadapi dan rasakan. Walaupun dari guru tidak menutup kemungkinan untuk bercerita. Sisi demikianlah dalam pandangan pendidikan pembebasan "murid yang guru" dan di saat yang sama juga "guru yang murid." Dari keduanya tidak ada yang merasa mana yang paling tahu. Tetapi sama-sama mendorong untuk belajar saling mengetahui.

Dalam metode pilihan yang diarahkan terjadi dialog antar keduanya. Pandangan guru tidak selamanya ia yang paling tahu, murid dibebaskan berekspresi terserah maunya apa, apa yang ia kehendaki dari minat dan bakatnya. Selama itu semua masih dalam batas-batas yang tidak melebihi kewajaran, anak dididik dan dibimbing sesuai dengan kepribadiannya. Sebagaimana ungkapan bapak Kobayashi: "jangan mengkotak-kotakkan anak dengan rencana guru. Biarkan mereka lepas di alam bebas. Cita-cita anak jauh lebih besar dari rencana guru.”

Anak didik merupakan manusia unik, yang mempunyai kesiapan 


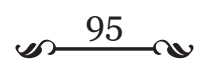

dan kemampuan fisik, psikis serta intelektual yang berbeda satu sama lainnya. Demikian pula halnya dengan proses belajar, setiap peserta didik mempunyai karakteristik berbeda. Muhtar Yahya berpendapat untuk menciptakan situasi mampu mendidik dengan kompetensi terpadu, dalam artian pendidik mempunyai tanggungjawab atas pendidikan anak didik. Pendidik itu memiliki sifat-sifat yang jelas dan ideal yang membantunya dalam kesempurnaan ilmu dan kesuksesan fungsi. Pendidik ideal adalah yang memiliki sifat aqliyyah (intelektualitas), jasmaniyyah (fisik), akhlaqiyyah (moralitas), yang akhirnya akan menuntut pada penguasaan segi-segi kognitif, psikomotorik, dan afektif peserta didik. Hal inilah yang ditekankan pula dalam pendidikan, masa anak-anak merupakan masa yang unik dan itu dialami anak sendiri.

Jika hal demikian ini yang dipegang dan terinspirasi dalam jiwa pendidik, maka metode karyawisata pun bagian dari suasana pembelajaran yang cukup adequateuntuk mengantarkan situasi dan kondisi jiwa anak didik, untuk tidak merampas dari realita dunianya. Metode karyawisata yang berupa jalan-jalan, berkemah ke tempat pemandian air panas dalam pendidikan Islam belum begitu "dikenal” di MI. padahal dalam karyawisata tersebut berkaitan dengan sumber daya alam, pada sisi tertentu alam ini untuk membuka kemungkinan eksploitasi, dan di sisi lainnya keharusan menjaga kelestarian alam dalam keseimbangannya yang sempurna (Yasmadi, 2002: 149).

Pendidikan dasar ulama' terdahulu hanyalah penekanannya pada materi normatif-religious, Ibn Kholdun misalnya, tentang materi pendidikan dasar pada membaca dan menulis, berkutat pada al-Qur'anHadits (Madjidi, 1997: 132). Kemudian, bila kembali pada masa sebelum Nabi Muhammad peradaban Arab tentang pembelajaran seni, terutama musik tidak ketinggalan dengan peradaban seni musik pada masa sekarang seperti rebana. Dalam pandangan al-Ghazali menetapkan kebolehan musik. Beliau mendasarkan pada nash al-Qur'an maupun Hadits dan qiyas, seperti mengqiyaskan suara yang keluar dari alat musik dengan suara burung. Jenis alat musik seperti guitar, serunai, dan kubah menurut al-Ghazali adalah jenis musik yang diharamkan, karena menjadi simbol peminum khamr.

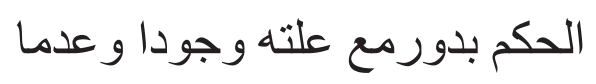




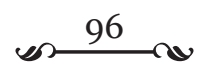

Berarti ketika illat itu berubah, maka hukum pun berubah. Dengan demikian jenis alat musik tersebut dapat menjadi halal, jika sudah tidak menjadi simbol bagi peminum khamr (Hasmy, 1975: 277). Hal tersebut berkaitan dengan metode ritmik sebagai penyeimbang kepekaan hati dan tubuh serta lingkungan yang diterapkan SD Tomoe sebagai metode pendidikannya. Jadi bentuk praktik pendidikan yang diterapkan tersebut masih dalam koridor pendidikan Islam. Wacana ritmik atau musik juga menjadi bagian vital dalam sekolah modern ini (Dryden, 2000: 179). Bukan hanya demikian, anak SD Tomoe hampir seluruhnya menggunakan metode pendidikan yang mendasarkan dataran praktis, yang mana paling mudah dalam masa anak merupakan masa meniru (imitation). Sehingga metode sosiodrama dan bermain peran dan demonstrasi diterapkan sebagai metode pendidikan dalam proses pembelajaran untuk mencapai tujuan pendidikan terhadap anak didiknya.

Metode sosiodrama dan bermain peran menguji keberanian titik pangkalnya pada sosok manusia pemberani dalam kebenaran yang mampu menguasai ketakutannya, kecuali kepada Alloh SWT. Demikian juga demonstrasi yang diperagakan oleh Bapak guru pertanian tanpa syarat apapun dapat menjadi guru pertanian. Kompetensi guru, di SD Tomoe ini menggunakan guru yang benar-benar mengerti tentang materi yang akan diajarkan. Guru pertanian ini dilakukan oleh seorang petani yang hanya berbekal pengalaman profesinya, ia mampu mengajarkan ilmu-ilmunya kepada anak didiknya. Ini mengandaikan pada pendidikan di MI, tentunya mampu mendidik anak didiknya dengan memperagakan hal-hal yang kiranya harus dipraktekkan dan ini lebih efisien dan efektif diterima oleh pemahaman anak didik.

Pembahasan metode pendidikan ini memberi warna terhadap metode pendidikan dalam lembaga pendidikan Islam seperti MI dikatakan tradisional, karena mengarah pada metode pendidikan teacher-centred. Sedangkan di sisi lain pendidikan kemandirian yang diartikan M Athiyah al-Abrasyi dengan pendidikan kemerdekaan dan kemandirian anak didik untuk berekspresi serta kemerdekaan untuk mengaktualisasikan diri sesuai dengan kemampuan dan bakat dengan dasar percaya diri tanpa harus mengikuti pendapat orang lain (al-Abrasyi, 1993:16). Ini selaras dengan SD Tomoe dalam metode pendidikan, yakni guru harus memberi kebebasan anak didik tanpa menganggap dirinya sebagai sumber utama, 


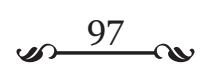

guru hanya fasilitator.

Metode pendidikan SD Tomoe ini berkaitan dengan nilai-nilai moral yang berlaku di masyarkat tertentu, bebas dari ideology, bisa juga dikaitkan dengan pendidikan pembebasan yang demokratis dan humanis ini relevan, yang pada pangkalnya menuju pada konsientasi-penyadaran diri secara kritis (Freire, 2001: 101-102). Penyadaran kritis anak didik untuk perkembangan pendidikan dasar, di masa anak-anak berumur 6-7 tahun. Dalam wacana psikologi, masa inilah yang paling menentukan perkembangan awal anak didik dalam perkembangan selanjutnya. Demikianlah metode pendidikan yang diterapkan SD Tomoe dalam mengkonstruk metode pendidikan di MI.

\section{Metode Pendidikan MI berbasis SD Tomoe menatap tantangan masa depan dunia pendidikan}

Lembaga pendidikan dapat dikatakan berhasil bila lembaga tersebut menghasilkan pencapaian pembelajaran dalam segala domain. Ada dua jenis standar dalam pendidikan yang dalam hal ini memungkinkan sebagai standar keberhasilan sekolah, yaitu standar akademis(academic content standard) dan standar kompetensi (performance standard). Standar akademis merefleksikanpengetahuan dan ketrampilan essensial setiap disiplin ilmu yang harus dipelajar oleh seluruh peserta didik.Sedangkan standar kompetensi ditunjukkan dalam bentuk proses atau hasil kegiatan yang didemonstrasikanoleh peserta didik sebagai penerapan dari pengatahuan dan ketrampilan yang telah di pelajarinya. Dengan demkian standar akademis bisa sama untuk seluruh peserta didik, tetapi standar kompetensi berbeda (Mulyasa, 2002: 24).

Pandangan penulis, standar kompetensi merupakan jawaban atas keberhasilan akademis, di mana kompetensi anak didik juga bagian dari standar kompetensi akademik anak didik. Standar kompetensi anak didik SD Tomoe mewujudkan anak didik yang dapat dipercaya pada dirinya sendiri dan dapat mengekspresikan kepribadiannya. Pada bagian akhir catatan buku Tetsuko Kuroyanagi bahwa murid-murid seperti Takahashi bertubuh pendek selalu percaya diri dari murid lainnya, termasuk Tetsuko sendiri yang menjadi komite UNICEF dan banyak prestasi lainnya. Meskipun ini semua tidak satu-satunya yang menjadi penentu Takahashi menjadi staf pada PT. Ando Elektrik, Miyo-chan sebagai pengajar musik, 


\section{(28}

Taiji sebagai wakil direktur "Lembaga Penelitian Akselerasi Negara Fermi” di Illionis USA dan teman-temannya berhasil. Keberhasilan seperti itu berkat dari baik secara langsung ataupun tidak langsung pengaruh proses pendidikan SD Tomoe yang melekat di pribadi masing-masing muridnya. Hal demikian yang mencorakkan standar akademis SD Tomoe konsentrasi terhadap pendidikan dasar yang menuntut kompetensi anak didik, bukan pendidik yang mengajari segalanya.

Dari paradigma metode pendidikan berwawasan pembebasan dan kemandirian praktek operasional tersebut sekiranya dapat diterapkan dalam sistem pendidikan dasar di Indonesia pada umumnya dan pendidikan Islam pada khususnya di MI, tanpa ada ekses ideologi tertentu yang menumpanginya. Lebih strategis lagi, di era reformasi ini konsep otonomi daerah merupakan titik acuan untuk membangun otonomi pendidikan dengan menyesuaikan materi dan metode pendidikan sesuai kondisi zaman dan masyarakatnya. Pada akhirnya menuju proses pembelajaran yang berpusat pada siswa, belajar dengan melakukan, mengembangkan kemampuan sosial, mengembangkan keingintahuan, imajinasi dan fitrah bertuhan, mengembangkan ketrampilan pemecahan masalah, mengembangkan kreatifitas siswa, mengembangkan kemampuan menggunakan ilmu pengetahuan dan teknologi, menumbuhkan kesadaran sebagai warga negara yang baik, belajar sepanjang hayat dan perpaduan kompetisi, kerjasama dan solidaritas.

\section{Simpulan}

SD Tomoe telah menerapkan beberapa metode pendidikan di antaranya adalah metode cerita, metode pilihan, metode karyawisata, metode ritmik, metode sosiodrama bermain peran, dan metode demonstrasi. Penamaan metode tersebut hampir sama dengan metode pendidikan yang telah diungkap beberapa ilmuwan pendidikan. Namun dalam dataran praktis operasional metode pendidikan yang diterapkan SD Tomoe berbeda, dan penulis menganalisis serta menyimpulkan bahwa metode pendidikan SD Tomoe lebih berorientasi: (a) pada student-centered(anak didik), bukan teacher-centered,(b) pada filosofis bebas ideologis tertentu, bebas nilai (value-free), namun tetap bertumpu pada aksiologi masyarakat, dan (c) pada pendidikan pembebasan demokratis, humanis, konsientiasi (penyadaran).

Berdasarkan hal tersebut, penelaahan metode pendidikan SD Tomoe 


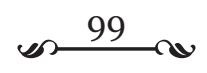

memiliki kontribusi dalam membangun konstruk metode pendidikan di Madrasah Ibtidaiyah. Kemudian catatan dalam metode pendidikan di MI adalah:(a) selayaknya harus menekankan pada student-centered (anak didik), (b) berada dalam batas medan netral dari ayat-ayat al-Qur'an maupun Hadits menjadi ideologi tertentu yang kadang membelenggu dalam mengembangkan metode pendidikan, sehingga ini menuntut pembacaan wacana realitas perlu mendapat porsi seimbang, sebagaimana pembacaan pada SD Tomoe ini,(c) memperhatikan sisi demokratis, humanis, dan konsientiasi. Demikianlah pembacaan penulis dalam konstruk metode pendidikan MI dalam parameter norma operasional metode pendidikan.

Metode pendidikan SD Tomoe ini menginspirasi dari pengertian kompetensi dalam yang diartikan sebagai pengetahuan, ketrampilan, dan kemampuan yang dikuasai oleh peserta didik yang telah menjadi bagian dirinya sendiri, sehingga ia dapat melakukan perilaku kognitif, afektif, dan psikomotorik dengan sebaik-baiknya di MI. 


\section{שת 100 \\ DAFTAR PUSTAKA}

al-Abrasy, M. Athiyah. 1993. Dasar-dasar Pokok Pendidikan Islam, Bustami dkk penj., Jakarta: Bulan Bintang, Cet., VII

al-Syaibani, Omar Mohammad al-Toumy. 1979. Falsafah Pendidikan Islam, Jakarta: Bulan Bintang, Cet., 1

an-Nahlawi, Abdurrahman. 1995. Pendidikan Islam di Rumah, Sekolah, dan Masyarakat, Shihabuddin penj., Jakarta: Gema Insani Press, Cet., I

Arief, Armai. 2002. Pengantar Ilmu dan Metodologi Pendidikan Islam, Jakarta: Ciputat Press, Cet., I

Arifin, M. 1996. Filsafat Pendidikan Islam, Jakarta: Bumi Aksara, Cet., V

Asari, Hasan. 1999. Nukilan Pemikiran Islam Klasik: Gagasan Pendidikan al-Ghazali, Yogyakarta: Tiara Wacana, Cet., I

Budiman, M. Nasir. 2001. Pendidikan dalam Perspektif al-Qur'an, Jakarta: Madani Press

Chan, M. 2002. Pendidikan Liberal Berbasis Sekolah, Abdul Munir Mulkhan dan Umi Yawisah penyadur, Yogyakarta: LPKM, 2002

Daradjat, Zakiah. 1995. Pendidikan Islam dalam Keluarga dan Sekolah, Jakarta: Ruhama

Dryden, Gordon dan Janette Vos. 2000. Revolusi Cara Belajar (The Learning Revolution) Belajar akan Efektif kalau Anda dalam Keadaan "Fun" Bagian I:Keajaiban Pikiran, Bandung: Kaifa, Cet., I

Hanafi, Hasan. 2003. Dari Aqidah ke Revolusi: Sikap Kita Terhadap Tradisi Lama, Asep Ismail penj., Jakarta: Paramadina, Cet., I

Hasmy, A. 1975. Sejarah Kebudayaan Islam, Jakarta: Bulan Bintang

Jalaluddin dan Usman Said. 1996. Filsafat Pendidikan Islam: Konsep dan Perkembangan Pemikirannya, Jakarta: PT Raja Grafindo Persada, Cet., II

Kuroyanagi, Tetsuko. 1986. Totto-chan Si Gadis Kecil di Tepi Jendela,Latiefah H. Rahmat dan Nandang Rahmat penj., (Jakarta, PT Pantja Simpati, Cet., IV

Madjidi, Busyairi. 1997. Konsep Pendidikan Para Filosof Muslim, Yogyakarta: Al-Amin Press, Cet., I

Mastuhu. 1999. Memberdayakan Sistem Pendidikan Islam, Jakarta: Logos, Cet., II 


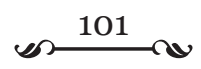

Mohammad, Goenawan. 1989. Catatan Pinggir 2, Jakarta: Pustaka Utama Grafiti

Munandar, S.C Utami. 1985. Mengembangkan Bakat dan Kreativitas Anak Sekolah; Petunjuk bagi Guru dan Orang Tua, Jakarta: PT. Gramedia, Cet., III

Nagaki, Michio. 1993. Pergulatan Jepang dalam Modernisasi Pendidikan, Arifin Bey penj., Jakarta: PT Gramedia Pustaka Utama

PP No. 17 Tahun 2010 tentang Pengelolaan dan Penyelenggaraan Pendidikan Purwanto, Ngalim. 2002. Ilmu Pendidikan: Teoritis dan Praktis,

Qutb, Muhammad. 1993. Sistem Pendidikan Islam, Bandung: PT al-Maarif, Cet., III

Rofik. 2003. "Konsep Pendidikan Mukhtar Yahya (Telaah Tri Pusat Pendidikan)," Jurnal Ilmu Pendidikan Islam, Vol. 4 No. 1, Januari 2003.

Sa'abah, Marzuki Umar. 2001. Perilaku Menyimpang dan Seksualitas Kontemporer Umat Islam, Jakarta: UII Press, Cet., I

Shaleh, Abdul Rahman. 2000. Pendidikan Agama dan Keagamaan: Visi, Misi, dan Aksi, Jakarta: PT Gemawindu Panca Perkasa, Cet., I

Syadli. 2001. Kecerdasan Emosional Siswa Dan Implikasinya Terhadap Kreativitas Guru Agama(Survei Terhadap Guru Agama SDN di Banten), dalam buku Simuh dkk, Islam Dan Hegemoni Sosial, Jakarta: Media Cita

Tafsir, Ahmad. 1994. Ilmu Pendidikan dalam Perspektif Islam, Bandung: PT Remaja Rosdakarya, Cet., II

Tanlain, Wens. 1996. Dasar-Dasar Ilmu Pendidikan, Jakarta: Pustaka Utama Gramedia.

Taruna, J. C. Tukiman. 2002. "Pedas dan Pakem: Komitmen dan Revolusi Pembelajaran" dalam majalah Basis. No. 07-08 Tahun ke-51 JuliAgustus

Tim Dosen IKIP Malang. 1980. Pengantar Dasar-Dasar Kependidikan, Surabaya: Usaha Nasional

Tritton, A.S. 1957. Materials on Muslim Education in The Middle Age, London: Lucaz dan Co. Ltd

Usman, M. Basyiruddin. 2002. Metodologi Pembelajaran Agama Islam, 
Jakarta: Ciputat Press, Cet., I

UU No. 20 Tahun 2013 tentang Sistem Pendidian Nasional

Yasmadi. 2002. Modernisasi Pesantren: Kritik Nurcholish Madjid terhadap

Pendidikan Islam Tradisional, Jakarta: Ciputat Press, Cet., I

Zuhairini. 1997. Sejarah Pendidikan Islam, Jakarta: Bumi Aksara, Cet., V 